\title{
Evidence of increased platelet activation after thrombolysis in patients with acute myocardial infarction
}

Cardiac Division of
the Department of
Medicine, Karolinska
Institutet, Huddinge
University Hospital
and Department of
Blood Coagulation
and Clinical
Chemistry, Karolinska
Hospital, Stockolm,
Sweden
G Rasmanis
O Vesterqvist
K Gréen
O Edhag
P Henriksson
Correspondence to:
Dr Peter Henriksson,
Cardiac Division,
Department of Medicine,
Huddinge University
Hospital, S-141 86
Huddinge, Sweden.
Accepted for publication
15 January 1992 .

Cardiac Division of Institutet, Huddinge University Hospital and Department of

Chemistry, Karolins

Swede

Gasmanis

Vesterqvist

K Gréen

P Henriksson

Correspondence to: Cardiac Division

Department of Medicin Huddinge, Sweden. Accepted for public

\begin{abstract}
Objective-To assess platelet activation after thrombolysis in patients with acute myocardial infarction.

Design-Platelet function was assessed by measurement of the in vivo synthesis of thromboxane by gas chromatographymass spectrometry of thromboxane's major urinary metabolite, 2,3-dinorthromboxane- $B_{2}$.

Setting-Coronary care unit of Huddinge University Hospital.

Subjects-30 patients with acute myocardial infarction given either streptokinase 1.5 million units intravenously over one hour $+500 \mathrm{mg}$ aspirin $(\mathrm{n}=10)$, $500 \mathrm{mg}$ aspirin $(\mathrm{n}=10)$, or neither thrombolysis nor aspirin $(n=10)$.

Results-Patients treated by thrombolysis had a $\mathbf{2 0 - f o l d ~ i n c r e a s e ~ i n ~ t h r o m - ~}$ boxane formation during thrombolysis compared with control patients not treated by thrombolysis $(p=0.0001)$. Until two days after thrombolysis thromboxane production in patients treated with streptokinase did not decrease to a value comparable with patients treated with aspirin but not given thrombolysis.

Conclusions-Thromboxane production increased considerably during thrombolysis, possibly reflecting greatly enhanced platelet activation. The slow decrease in thromboxane formation after treatment with aspirin suggests that the efficacy of thrombolysis might be improved by more efficient antiplatelet treatment.
\end{abstract}

(Br Heart J 1992;68:374-6)

Table 1 Data on 10 patients treated with streptokinase infusion (1.5 million units $/ 60$ min) within six hours after onset of symptoms of myocardial infarction (MI)

\begin{tabular}{|c|c|c|c|c|c|c|c|c|c|}
\hline \multirow[b]{2}{*}{ Case } & \multirow[b]{2}{*}{ Age } & \multirow[b]{2}{*}{ Sex } & \multirow[b]{2}{*}{ Smoker } & \multirow[b]{2}{*}{ Previous MI } & \multirow[b]{2}{*}{$\begin{array}{l}\text { Duration of } \\
\text { pain }(h)\end{array}$} & \multirow[b]{2}{*}{$\begin{array}{l}C K-M B \text { peak } \\
(\mu k a t / l)\end{array}$} & \multirow[b]{2}{*}{$\begin{array}{l}\text { Time to enzyme } \\
\text { peak }(h)\end{array}$} & \multicolumn{2}{|c|}{$\begin{array}{l}\text { Excretion during } \\
\text { infusion of streptokinase } \\
\text { (pg/mg creatinine) }\end{array}$} \\
\hline & & & & & & & & $P G I_{2 m}$ & $T x A_{2 m}$ \\
\hline $\begin{array}{r}1 \\
2 \\
3 \\
4 \\
5 \\
6 \\
7 \\
8 \\
9 \\
9 \\
10\end{array}$ & $\begin{array}{l}69 \\
59 \\
37 \\
59 \\
72 \\
50 \\
73 \\
72 \\
74 \\
80\end{array}$ & $\begin{array}{l}\mathbf{F} \\
\mathbf{F} \\
\mathbf{M} \\
\mathbf{M} \\
\mathbf{M} \\
\mathbf{M} \\
\mathbf{F} \\
\mathbf{M} \\
\mathbf{M} \\
\mathbf{M}\end{array}$ & $\begin{array}{l}\overline{\text { Yes }} \\
\text { Yes } \\
\text { Yes } \\
\overline{\text { Yes }} \\
\overline{\text { Yes }} \\
\text { Yes } \\
-\end{array}$ & $\begin{array}{l}- \\
\overline{-} \\
\bar{Y} \\
\text { Yes } \\
\text { Yes } \\
\overline{\text { Yes }} \\
-\end{array}$ & $\begin{array}{l}6 \\
4 \cdot 5 \\
6 \\
2 \\
1 \\
2 \\
3 \\
5 \\
2 \cdot 5 \\
2.5\end{array}$ & $\begin{array}{l}6.1 \\
6.5 \\
8.9 \\
6.5 \\
4 \\
5.2 \\
5.4 \\
3.7 \\
0.7 \\
1.1\end{array}$ & $\begin{array}{l}12 \\
18.5 \\
18.5 \\
12.5 \\
10 \\
10 \\
25 \\
13 \\
8.5 \\
17\end{array}$ & $\begin{array}{r}353 \\
592 \\
1340 \\
772 \\
675 \\
937 \\
140 \\
1522 \\
391 \\
908\end{array}$ & $\begin{array}{r}709 \\
4922 \\
29196 \\
3266 \\
2716 \\
5534 \\
1021 \\
2158 \\
1492 \\
90737\end{array}$ \\
\hline Mean (SEM) & \multicolumn{9}{|c|}{$64.5(3.4)$} \\
\hline
\end{tabular}

CK-MB, creatine phosphokinase isoenzyme $M B$. $\mathrm{PGI}_{2 \mathrm{~m}}$, prostacyclin metabolite; $\mathrm{T} \times \mathrm{A}_{2 \mathrm{~m}}$, thromboxane metabolite.
Platelet are activated in coronary thrombotic diseases such as acute myocardial infarction and unstable angina pectoris ${ }^{1-3}$ and aspirin treatment was found to prevent myocardial infarction and deaths in patients with unstable angina and myocardial infarction. ${ }^{4-6}$ Aspirin irreversibly acetylates the enzyme cyclooxygenase and thereby inhibits the synthesis of the potent platelet aggregator thromboxane $\mathrm{A}_{2}{ }^{7}$ We found that aspirin was a very efficient inhibitor of thromboxane synthesis in patients with acute myocardial infarction. ${ }^{8}$ These patient's however, were not treated with thrombolytic agents. The beneficial effect of thrombolysis on mortality ${ }^{69}$ has made it the standard treatment for patients with myocardial infarction. The higher reinfarction rate in patients given streptokinase without aspirin $^{6}{ }^{1011}$ prompted us to study the effect of aspirin on the in vivo synthesis of thromboxane and prostacyclin in patients with acute myocardial infarction given thrombolysis.

\section{Patients and methods} infarction admitted to our coronary care unit within six hours of the onset of symptoms (3.3 $(0 \cdot 5) \mathrm{h}$ (mean (SE)). The patients had not taken aspirin or any other cyclo-oxygenase inhibitor in the $\mathbf{1 0}$ days before the infarction and all gave their informed consent to the study. Regular medications were continued-that is, patients were given $\beta$-blockers if there was no contraindication, and glyceryl trinitrate and diuretics were given as necessary. All patients were given streptokinase (Behring, Marburg, Germany) ( 1.5 million units intravenously over one hour). Immediately after this the patients were given 
Table 2 Comparison of peak enzyme and protanoid concentrations (mean (SEM)) during myocardial infarction in patients given thrombolysis and aspirin $(n=10)$ with controls not given thrombolysis (but given aspirin $(n=10)$; and controls given neither $(n=10)$

\begin{tabular}{lllllll}
\hline & Age $(y)$ & Sex (female (\%)) & Smokers (\%) & $\begin{array}{l}\text { CK-MB peak } \\
(\mu k a t / l)\end{array}$ & \multicolumn{2}{c}{ Peak (pg/ml creatinine) } \\
\cline { 3 - 7 } & PGI $m$ & $T x A_{2} m$ \\
\hline SK + aspirin & $64 \cdot 5(3 \cdot 4)$ & $30 \%$ & $60 \%$ & $4 \cdot 8(0 \cdot 7)$ & $1187(449)$ & $11966(7514)$ \\
Aspirin & $60 \cdot 7(3 \cdot 5)$ & $20 \%$ & $40 \%$ & $3 \cdot 2(0 \cdot 6)$ & $1078(491)$ & $522(137)$ \\
Controls & $63 \cdot 9(2 \cdot 1)$ & $10 \%$ & $30 \%$ & $3 \cdot 1(0 \cdot 6)$ & $755(268)$ & $650(145)$ \\
\hline
\end{tabular}

SK, streptokinase; $\mathrm{CK}-\mathrm{MB}$, creatine kinase isoenzyme $\mathrm{MB} ; \mathrm{PGI}_{2} \mathrm{~m}$, prostacyclin metabolite; $\mathrm{T} \times \mathrm{A}_{2} \mathrm{~m}$, thromboxane metabolite.

aspirin $(500 \mathrm{mg}$ ) in buffered water solution (Bamyl-S, Hassle, Sweden) and this treatment was repeated every third day. Urine was collected before treatment, soon after thrombolysis, and then as 24 hour collections for days $1,2,3$, and 7.

Table 1 gives data on the individual patients. As controls we used 20 patients with myocardial infarction who were not given thrombolysis. Those patients were recruited before thrombolysis and aspirin became the routine treatment at our coronary care unit. They had no contraindications to the use of aspirin and in all respects resembled the thrombolysis patients. Ten of the controls were given neither aspirin nor streptokinase and 10 were given aspirin in the same protocol as the patients treated with thrombolysis.

Otherwise all 30 patients were treated in an identical way-that is, were given $\beta$-blockers if there was no contraindication, and glyceryl and diuretics were given when necessary. Patient characteristics were matched. Acute myocardial infarction was diagnosed by the WHO criteria. The study was approved by the ethics committee at Huddinge University Hospital.

\section{ANALYSIS}

Urinary 2,3-dinor- $\mathrm{TxB}_{2}$ and 2,3-dinor-6-keto$\mathrm{PGF}_{1 \alpha}$ were analysed by gas chromatographymass spectromety, with tetra-deuterated carriers and internal standards. ${ }^{1213}$
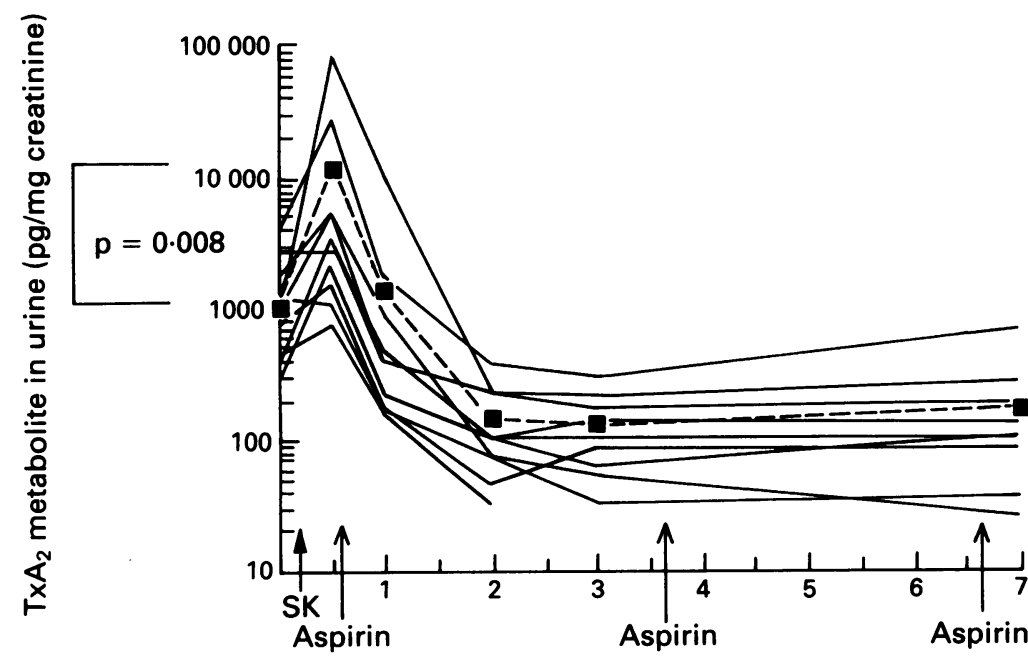

Days

Figure 1 Urinary excretion of a thromboxane $\left(T x A_{2}\right)$ metabolite $\left(2,3\right.$ dinor- $\left.T x B_{2}\right)$ in 10 patients treated with inf usion of streptokinase $(S K)$ followed by an intermittent dose of aspirin ( $500 \mathrm{mg}$ each third day). Mean is shown by a broken line.

\section{STATISTICAL METHODS}

Results are given as mean (SE) and analysed by analysis of variance. Because thromboxane values after thrombolysis were not normally distributed the data were logarithmically transformed before analysis.

\section{Results}

All patients had a transmural infarction. Baseline characteristics and infarction variables such as peak enzyme concentrations, age, sex, and previous treatment with $\beta$ blockers were similar for patients given thrombolysis and for control patients (table 2). Infusion of streptokinase increased the initial thromboxane metabolite concentration 10-fold (fig 1) and the peak concentration was approximately 20 times higher than in the two control groups (fig $2 ; p=0.0001$ ).

As figs 1 and 2 show, thromboxane production fell after the first dose of $500 \mathrm{mg}$ aspirin, but only to a concentraton similar to that found in control patients not treated with aspirin or thrombolysis. On the second day after thrombolysis thromboxane production had fallen to the same concentration as measured in the patients treated with aspirin but not thrombolysis (fig 2). Peak prostacyclin concentrations were increased to a similar extent in all groups (table 2).

One patient in the thrombolysis group died of severe congestive heart failure on the third day. There were no reinfarctions within a 30 day period. Furthermore, no side effects of aspirin were reported. Glyceryl trinitrate consumption was similar in the three groups.

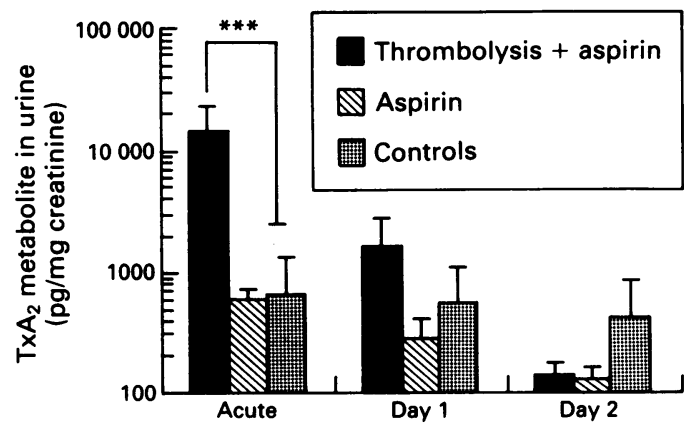

Figure 2 Urinary excretion of a thromboxane ( $T x A_{2}$ metabolite $(2,3$-dinor-TxB $)$ in patients with an acute metabolite $\left(2,3-\right.$ dinor- $\left.T x B_{2}\right)$ in patients with an acute
myocardial infarction treated with streptokinase $(S K)$ and aspirin: thrombolysis + aspirin $(n=10)$; only aspirin $(n=10)$, or neither $(n=10)$. Values are mean $(S E M) .{ }^{\star \star \star} p<0.001$. 


\section{Discussion}

We found a 20 -fold increase in thromboxane formation when patients with acute myocardial infarction were treated with thrombolysis. The most obvious explanation for this finding was that platelet activation was increased during thrombolysis. Fitzgerald et al reported a similar tendency for thromboxane production to increase during thrombolysis in two patients. ${ }^{14}$

Patients given thrombolysis without antiplatelet therapy are reported to have an increased reinfarction rate, ${ }^{61011}$ probably reflecting reocclusion of previously opened coronary arteries. Furthermore, repeated angiography has shown evidence of early reocclusion. ${ }^{15}$ In a study reported by Six et al there was evidence suggesting that the higher the dose of streptokinase the higher the initial patency rate but also the higher the reinfarction rate. $^{16}$

Our findings accord with the suggestion that the increase in reinfarction rate is caused by greatly enhanced platelet activation/instability (as shown by the increase in thromboxane formation). In the ISIS-2 study the addition of aspirin to streptokinase reduced mortality even further. ${ }^{6}$ The dose of aspirin given in ISIS-2 was only about a quarter of the dose we gave. Despite the higher dose of aspirin in our study it was not until day 2 that thromboxane production fell to values found in patients with acute myocardial infarction who were treated with aspirin but not thrombolysis. These results indicate that the efficacy of thrombolysis could be improved if patients were also given more effective antiplatelet therapy. Perhaps the initial high patency rate could be better preserved if aspirin were given before thrombolysis or if a thromboxane receptor antagonist were given with a cyclo-oxygenase inhibitor or thromboxane synthase inhibitor. ${ }^{17}$ Our results may help to explain why treatment with low dose aspirin $(80 \mathrm{mg})$ in conjunction with thrombolysis was relatively ineffective. ${ }^{18}$

We found that thromboxane formation increased 20 -fold when patients with acute myocardial infarction were given streptokinase. This increase probably reflects a considerable platelet activation. Our results strongly suggest that the combination of thrombolysis with efficient antiplatelet therapy would improve results in patients with myocardial infarction, especially when thromboxane receptor antagonists become available.
This study was supported by grants from the Swedish HeartLung Foundation, the Swedish Labour Market Insurance Company, and the Swedish Medical Research Council (project number 07134, 08120).

1 Davies $M$, Thomas A, et al. Intramyocardial platelet aggregation in patients with unstable angina suffering sudden ischemic cardiac death. Circulation 1986;73:41827.

2 Vesterqvist $O$, Edhag $O$, Gréen $K$, Henriksson $P$. In vivo production of thromboxane in acute myocardial infarcproduction of thromboxane in acute myocardial infarc-

3 Henriksson P, Wennmalm $\AA$, Edhag O, Vesterqvist $O$, Gréen $K$. In vivo production of prostacyclin and thromboxane in patients with acute myocardial infarction. $\mathrm{Br}$ Heart $J$ 1986;55:543-48.

4 Lewis HD Jr, Davis JW, Archibald DG, et al. Protective effects of aspirin against acute myocardial infarction and death in men with unstable angina. $N$ Engl $J$ Med 1983;309:396-403.

5 Cairns JA, Gent M, Singer J, et al. Aspirin, sulfinpyrazone or both in unstable angina. $N$ Engl J Med 1985;313:136975.

6 ISIS-2. Collaborative Group Randomised trial of intravenous streptokinase, oral aspirin, both, or neither among 17187 cases of suspected acute myocardial infarction: ISIS-2. Lancet 1988;ii:349-60.

7 Hamberg M, Svensson J, Samuelsson B. Thromboxanes: a new group of biologically active compounds derived from prostaglandin endoperoxides. Proc Natl Acad Sci USA prostaglandin endo

8 Rasmanis G, Vesterqvist $O$, Gréen K, Edhag O, Henriksson $P$. Effects of intermittent treatment with aspirin on thromboxane and prostacyclin formation in patients with acute myocardial infarction. Lancet 1988;ii:245-7.

9 Gruppo Italiano Per Lo Studio Della Streptochinasi Nell' infarto Miocardio (GISSI). Effectiveness of intravenous thrombolytic treatment in acute myocardial infarction. Lancet 1986;i:397-402.

10 The ISAM Study Group. A prospective trial of intravenous streptokinase in acute myocardial infarction (ISAM) $N$ Engl J Med 1986;314:1465-71.

11 Chesebro J, Knatterud G, Roberts R, Borer J, Cohen L, et al. Thrombolysis in myocardial infarction trial (TIMI). Circulation 1987;76:142-54.

12 Vesterqvist $O$, Gréen $K$, Lincoln FH, Sebek OK. Development of a GC-MS method for quantitation of 2,3-dinorment of a GC-MS method for quantitation of 2,3-dinor$\mathrm{TXB}_{2}$ and determinations of the daily urinary excre
rates in healthy humans. Thromb Res 1983;33:39-49.

13 Vesterqvist $O$, Gréen K. Development of a GC-MS method for quantitation of 2,3-dinor-6-keto-PFG ${ }_{1 a}$ and determination of the urinary excretion rates in healthy humans under normal conditions and following drugs. Prostaglandins 1984;28:139-54.

14 Fitzgerald DJ, Catella F, Roy L, FitzGerald GA. Marked platelet activation in vivo after intravenous streptokinase in patients with acute myocardial infarction. Circulation 1988;77:142-50.

15 Stack R, O'Connor C, Mark D, et al. Coronary perfusion during acute myocardial infarction with a combined therapy of coronary angioplasty and high-dose intraventherapy of coronary angioplasty and high-dose
ous streptokinase. Circulation 1988;77:151-61.

16 Six J, Louwerenburg H, Braams R, et al. A double-blind randomized multicenter dose-ranging trial of intravenous randomized multicenter dose-ranging trial of intravenous streptokinase in

17 Golino P, Rosolowsky M, Yao S, Buja M, Willerson J, Blockade of $\mathrm{TxA}_{2}$ receptors and inhibition of $\mathrm{TxA}$ synthetase enhances thrombolysis and prevents reocclusion more efficiently than either intervention alone. Circulation 1989;80(II):113.

18 Hsia J, Hamilton WP, Kleimann N, et al. A comparison between heparin and low-dose aspirin as adjunctive therapy with tissue plasminogen activator for acute myocardial infarction. N Engl J Med 1990;323:1433-7. 